\title{
Exponential Organizations Hypergrowth Strategies and Firm Performance: The Moderating Role of Firm Size and Marketing Spending
}

\author{
Refaat Alfaouri, Hussam Alshammari, Hamza Tubaishat
}

\begin{abstract}
With the increasing concerns of hypergrowth in order to compete in the international markets and survive, this study aids all firms in various industries, entrepreneurs and decision makers and draw their attention to business models and hypergrowth strategies that are applied by the fast-growing firms in the world. This study investigates the impact of hypergrowth strategy- leveraging assets that developed by Salim, (2014) and firm performance in exponential organizations; The sample size tested constituted of (34) exponential organizations form the fortune 500 and multiple regressions via Stata version 15 was applied for the time period of (2016-2019). Preliminary analysis was conducted to check the assumptions related to the regression models which include unit root, autocorrelation, residuals normality and heteroskedasticity issues. The results showed significant positive relationships between Growth in Fixed Assets (leveraging Assets strategy) and firm performance measured by ROA and ROE whereas, the moderating role of marketing spending and firm size showed insignificant impact in the relationship
\end{abstract}

Keywords: Exponential Organizations, Hypergrowth, Firm size, Marketing spending.

\section{INTRODUCTION}

In the current markets, firms aiming to achieve accelerated growth in their market value through amass customers which could be gained by first mover advantage (Eisenmann, 2006). There are many researchers studied the hypergrowth firms; this term was first used by Alexander V. Izosimov in a 2008 issue of Harvard Business Review to describe the accelerated growth firms that achieves company's compound annual growth rate (CAGR) $40 \%$ or greater. The compound annual growth rate (CAGR) is known as the required rate of return for an investment to grow from its beginning balance to its ending balance (Izosimov, 2008).

Manuscript received on March 13, 2021.

Revised Manuscript received on March 30, 2021.

Manuscript published on March 30, 2021.

* Correspondence Author

Hamza Tubaishat*, Business Administration, Yarmouk University, Irbd, Jordan. Email: hamzeh2011.tubishat93@gmail.com

Refaat Faouri, Public Administration, Yarmouk University, Irbd, Jordan , Email: refatalfaouri@yahoo.com

Hussam Alshammari, Business Administration, Yarmouk University, Irbd, Jordan. Email: husam.shammari@yu.edu.jo

(C) The Authors. Published by Blue Eyes Intelligence Engineering and Sciences Publication (BEIESP). This is an open access article under the CC BY-NC-ND license (http://creativecommons.org/licenses/by-nc-nd/4.0/)
In 2014 Ismail Salim and his co-researchers have studied around 100 of the 500 fortune companies which has exponentially grown in the last five years and identified the common traits and strategies across all the exponential organizations and developed the Massive Transformative Purpose (MTP) as shown in the figure (1).

Organizations which adopt any four of the above mentioned 10 attributes can achieve exponential growth. The concept of exponential organization is defined as "one whose impact (or output) is disproportionally large - at least $10 \mathrm{x}$ larger-compared to its peers because of the use of new organizational techniques that leverage accelerating technologies" (Salim, 2014: P. 19).

The improvement in digital technology in the form of enhanced computing power, storage and bandwidth is fueling exponential growth of organizations (Kabaly \& Balanagarajan, 2018). But without exponential mind-set an ambitious vision wouldn't be exist for instance, Google vision "organizing the world's information" and Amazon vision "to be Earth's most customer-centric company, where customers can find and discover anything they might want to buy online" (Bonchek, 2016). There are many examples on exponential organizations (EXOs), YouTube which went from a start-up funded by Chad Hurley's personal credit card to be purchased by Google for $\$ 1.4$ billion in less than 18 months. Uber is valued almost $\$ 17$ billion, 10 times its value of two years ago only (Salim, 2014). Generally, in the launch phase of any business, managers and entrepreneurs need to develop and refine the business strategy to aid them in achieving their vision for the business regardless of their business being linear or exponential (Salim, 2014).

To date, no studies explored the financial performance outcome of the exponential organizations strategies those developed by Salim (2014). An empirical research on the relationship between marketing spending and financial performance is Sharma \& Husain (2015), but they were studied a mature and stable industry than focusing on new market or on the new business model; they studied the telecommunications industry in Saudi Arabia. Another study studied the new market and the hypergrowth is Lieberman (2002) study; he found that first movers in the Internet sector were more likely to realizing superior market valuations when their business models leveraged network effects. But he didn't study the financial performance outcome even if these companies achieving superior market valuation; depending on the above this study exploring the impact of leveraging assets as one of the ten hypergrowth strategies that developed by Salim, (2014). 


\section{Exponential Organizations Hypergrowth Strategies and Firm Performance: The Moderating Role of Firm Size and Marketing Spending}

In addition to this chapter, this paper includes the following four chapters. The first reviews relevant research and the developed hypotheses.

The second describes sample selection criteria and econometric methods. The third presents results. The final section analyses the results, discusses their generalizability, and considers implications for future research.

\section{PURPOSE OF THE STUDY}

Companies tend to take a strategic decision related to investment in fixed assets to achieve more gains and profits but The cost of such decisions is proportionally very high; hence, companies have to sacrifice an amount of their resources or they may incurring a long term debt to finance such decisions (Sánchez-Vidal \& Francisco, 2005). Eventually, companies incurred similar strategic decisions after intensive analysis about the future benefits that could be obtained from the investment (Adam, 2011). Another important goal for making such investment decisions is exploiting the benefit of first mover advantage by attracting more customers before new competitors enter the market (Fudenberg \& Tirole, 1987). This paper is testing the hypergrowth strategy of leveraging assets in superior performance firms and exploring whether such strategy as one of the ten hypergrowh strategies that developed by Salim, (2014) are affecting the financial performance of the sampled Exponential organizations in addition to aids in explaining the context of new business models and how they may benefits from leveraging assets.

This research evaluates factors that encouraged accelerated growth strategies and examines the long-term performance consequences of such strategies. As per Salim, (2014) leveraging assets is one of the strategies that incurring hyper growth on firm's performance. This study increases the awareness about the importance of the hypergrowth strategies incurred by the new breed of organizations. Babson's Olin Graduate School of business (2011), predicted that in the next ten years, $40 \%$ of companies that were founded before 20 years and more would not be able to survive; because these companies will no longer have the power that the new breeds of organizations have.

The study introduces a summary of previous studies performed in the same area. It is performed on a focused data sample that could guide decision makers and managers to choose the best practices for fixed assets' investments that maintain firm's hypergrowth success. Moreover, it would benefit entrepreneurs; who tend to invest aggressively in fixed assets enjoy future increase in returns (Eisenmann, 2006)

Furthermore, this study has a theoretical importance as well. It is considered as one of the few studies that have no precedent in business studies on exponential organizations (EXOs). Most previous studies focused on the effect of assets on financial performance growth only, and their results were diverse. For example, a study performed by Hsiang et al. (2006), indicated that there is a positive association between capital expenditure and a firm financial performance, while Sahu et al. (2001), concluded that there is no correlation. For EXOs there is no evidence about the impact of the capital expenditure on the growth of the firm market value or on the financial performance. However, the current study introduces a more recent and a specific set of data that is focusing on understanding the business model and the strategies employed by the hypergrowth firms. It adds one more set of empirical evidence that supports the hypothesis of the impact of capital expenditure on the financial performance and firm value. Also, the research presents strong evidence for managers who seek to enhance the financial performance of their firms.

\section{REVIEW OF LITERATURE AND HYPOTHESES}

A. The term "hypergrowth" was first used by Alexander V. Izosimov in a 2008 issue of Harvard Business Review. Where he defined hypergrowth as "the steep part of the curve that most young markets and industries experience at some point" (Izosimov, 2008: Para. 2). In order to achieve hypergrowth; managers need to foster can-do communication-friendly culture, in which employees are not afraid of failure. In addition, decisions should be pushed out to the front line, which saves time and puts decisions in the hands of more-decisive people (Izosimov, 2008).

Another researcher defined the accelerated growth strategies as the "efforts to acquire customers rapidly in new markets through heavy marketing spending, discounting aggressively, or absorbing rivals through mergers. Growth is 'accelerated' to the extent that a firm sacrifices current profits in order to maximize the present value of future profits" (Eisenmann, 2006: P.28). A firm's strategy can be operationalized in terms of the distribution of firm assets, sales, employment, capital budget, or other indices of firm resources among the range of existing industries (Eisenmann, 2006). Other researchers defined hypergrowth as "firms that have sales growth of $500 \%$ over five years" (Markman \& Gartner, 2002: P. 1).

Management consultant adduced that firm growth is essential to the success and longevity of any business. On the other hand, scholars say that growth creates employment, wealth, economic development that achieves welfare (MCGareth \& Kroeger , 2001).

Other researchers such as Sextone et al. (2000) found that the firm growth and profitability is correlated. They concluded that firms which finance their growth from capital investment or owners' equity were more profitable.

To further explain and understand hypergrowth, organizations life cycle theory must be addressed. As firms move through the lifecycle stages, they experience different organizational characteristics, problems, structural configurations and strategic or management priorities (Greiner, 1998). Researchers developed various organization life cycle models. For instance, Rurtherford et al. (2003) suggested around ten stages. This was further concluded by Kazanjian and Drazin (1990), through strong evidence to a usable three-stage model that it is indeed common for all organizations. Similarly, Tam \& Gary (2016), reached the same conclusion as well. They all emphasized that the most common model for organizations life cycle is the three stages model. The following paragraph includes a detailed explanation of the three stages model introduced by Kazanjian and Drazin (1990).

Inception Stage is the first stage of organization's life cycle. In this stage firms tend to have a more flat, flexible, less departments,

Published By:

Blue Eyes Intelligence Engineering and Sciences Publication

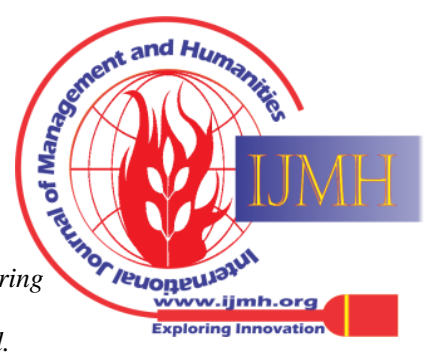


smaller, and informal structure (Spicer \& Sadler-Smith, 2006). High-growth stage the main characteristics are semi-formal, systematic and some new departments with more bureaucracy (Spicer \& Sadler-Smith, 2006). In this stage, the firm is rapidly growing and the need for new managers is necessary to share the responsibility and leadership (Kazanjian \& Drazin, 1990). Entering high growth stage of the organization life cycle requires shifts in firm structure, rewards system and methods of decision making (MCGareth \& Kroeger , 2001). These activities permit a growing firm to leverage its resource portfolio to support their competitive advantage (Sirmon et al., 2010).

The last stage is the maturity stage, which is attained when the firm aligns with its formal organizational structure, and the work becomes more documented. It is more hierarchical, resourceful and bureaucratic (Hanks \& Chandler, 1994). A firm in this stage becomes more stable with decentralized authority and is more efficient (Bruce \& scott, 1987).

\section{B. Exponential organizations}

The concept of exponential organizations addresses a new kind of organization structure That leverages openness, transparency and abundance (Salim, 2014). Ismail Salim the founder of exponential organizations (EXOs) concept developed the Massive Transformative Purpose (MTP). Figure (1) contains attributes that reflect the internal mechanisms and externalities to achieve exponential growth. The SCALE reflects the five external attributes and the IDEAS for the five internal attributes. As per Salim (2014), not every EXOs implement all the ten attributes, the two hemispheres of the brain used to frame EXOs attributes. The right brain manages growth, creativity and uncertainty, while the left-brain focuses on order, control and stability. Exponential organizations are the ones who grow bigger bypassing the incremental or linear way in which traditional organizations tend to grow. These organizations leverage the ability of digital technologies to create exponential value (Bonchek, 2016). The organization which has shown (10 times) performance increase than their industry peers are considered as "exponentials". Exponential organizations make use of the abundant information available with the help of technology for accessing or sharing work efficiently. These organizations are built upon information technologies which blends both the physical and digital worlds. They also make use of the ample external resources instead of owing and securing assets (Salim, 2014).

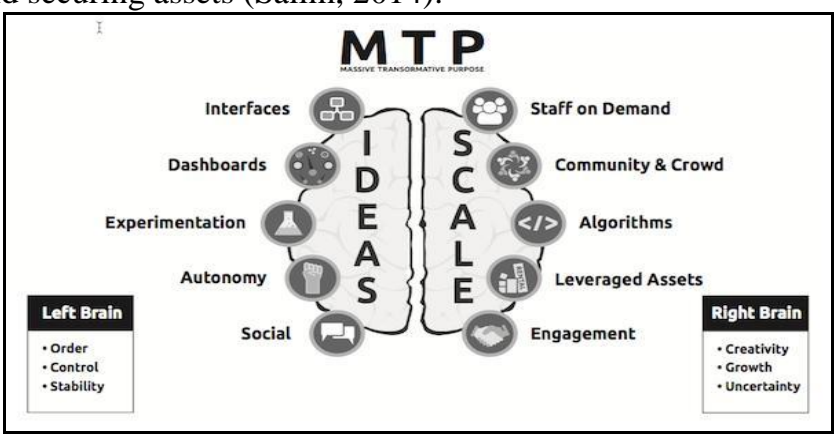

Figure(1)

Source: (Salim, 2014)

\section{Leveraging assets growth strategy and Organization} performance

The traditional way to business growth is the investment in fixed assets in another word, you own them. But the need to own assets is precisely what makes traditional growth strategies risky; you have to make your investment first, but the payoff comes later or much later.

But there is another kind of growth strategy, with law risk and offers the expected profitability. By this strategy owning is not always necessary expand If the needed assets are available and can be mobilized by outsourcing so you can capture the economic benefits of growth while avoiding the risk of asset ownership which may be financed by long-term debit (Hagel, 2002).

Asset sharing or leveraging assets can be best described as: If you flexibly access your assets rather than own them or just lease them when you need them. By leasing the assets firms and managers are not encumbered by their balance sheet and by trying to maximize the utilization of the assets. It is important to differentiate from financial leasing, which leaves you as slowed by your liabilities (Salim, 2014).

Eriotis et al. (2000), X-rayed the relationship between fixed assets and firm's profitability. The study used panel data for various industries, covering a period of 1995-1999. The main conclusion of the study is that firms use their investment in fixed assets as a strategic variable to positively affect profitability. Xing (2008), analysed the relationship between investment in assets and expected return in the USA using regression analysis. The data for 43,277 firms from 1964 to 2003 interpreted the value effect through the capital investment variation, as well as the capital investment divided by the total net asset, as a proxy for asset growth. The results showed a negative relation between investment and stock return. In addition, Cooper et al. (2008), used the total asset as a proxy for the sample of all NYSE, Amex, and NASDAQ nonfinancial firms; confirming the results of Xing (2008) by using the same method and same time period. They conclude that asset growth rates are strong predictors of future abnormal returns. Whereas Hsiang et al. (2006), examined the relationship between capital expenditure and corporate earnings for 357 manufacturing firms listed on the Taiwan Stock Exchange over the period 1992-2002. The sample period of 11 years is divided into capital investment period and performance period. Using regression method to test the relationship between capital expenditure and corporate earnings, the results indicated a significantly positive association between capital expenditure and future corporate earnings.

Furthermore, Qaddoumi (2015), in agreement with Hsiang et al. (2006), whose study aimed to identify the impact of capital expenditure (Capex) 1 on company's financial performance. The study addressed the Capital expenditure (Capex) value (independent variable) on a series of performance indicators such as return on assets (ROA), return on equity (ROE), earning per share (EPS), and stock market value (SMV). The study was conducted on a sample of 50 industrial companies listed in

${ }^{1}$ Capital expenditure (Capex) $=$ investment in fixed assets for the current year.

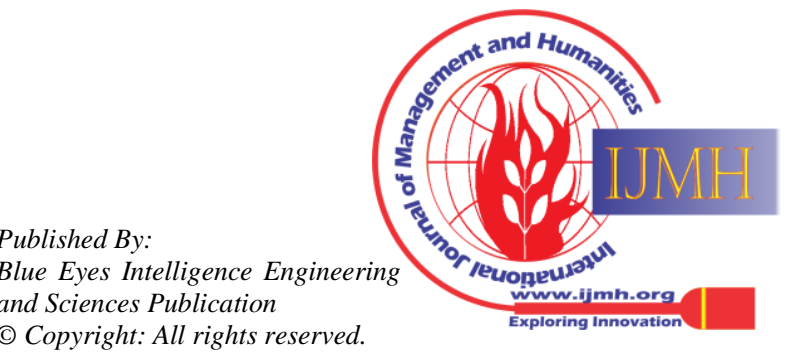




\section{Exponential Organizations Hypergrowth Strategies and Firm Performance: The Moderating Role of Firm Size and Marketing Spending}

Amman Stock Exchange for the period (2003 - 2012), using simple regression analysis and multi regression analysis, taking into Consideration Company's size as control variable. The study concluded that there was a strong impact of capital expenditure on each of ROA, EPS, and SMV and statistically significant.

Svetlana and Aaro (2012), studied the impact of companies' investment intensity on its return on assets (ROA). The researchers used regression analysis as the methodology on a sample of 8,074 companies in six European Union (EU) member states over a nine-year period from 2001 to 2009. Contrary to some previous studies, they could not identify any strong negative (or positive) impact of investment intensity on future rate of return on assets. Kotšina and Hazak (2012), examined the impact of investment intensity measured by the percentage of fixed assets to total assets and the return on assets using the same sample of Svetlana and Aaro (2012) study and for the same period (2001 to 2009). As a result, were able to confirm the results of Svetlana and Aaro (2012) study.

Moreover, Azadi (2013) examines the effects of changes in assets (fixed and current) on operating earnings in the Tehran Stock Exchange. Results showed that, for food and metal industries, the coefficient of variation of fixed assets has positive and a significant effect on operating earnings. However, for chemical industries, the coefficient of variation of current assets did not have a significant effect on operating earnings. The study further suggests that the effect of asset structure changes has a significant variance on operating assets and among different industries. Zhang (2017), follows an empirical approach to test the relationship between degree of intangible assets and profitability. All the data are based on 17 listed telecommunication firms' in China from 2014 to 2016. Using regression model this study gives empirical evidence that intangible assets' ratios have positive and a significant effect on firms' financial performance, measured by return on assets (ROA). for listed telecommunication companies in China.

Performance measures are either financial or organizational. Financial performance such as profit maximization is at the core of the firm's effectiveness. Organizational performance measures include growth in sales and growth in market value (Hoffer \& Sandberg, 1987). Ramli and Yusoff (2015) defined financial performance as the ability of an organization to utilize its resources to achieve organizational goals in an effective and efficient way. Other researchers stated that the financial performance is a subjective measure of how well a firm can use assets from its primary mode of business to generate revenues. The term is also used as a general measure of a firm's overall financial health over a given period of time (Gibson, 2008).

Based on the above, the following hypotheses are developed:

H1: Growth in fixed assets has a positive relationship with return on assets (ROA) ratio.

H2: Growth in fixed assets has a positive relationship with return on equity (ROE) ratio.

\section{Marketing spending}

Marketing Expenses is an organization's total expenditure on marketing activities. This typically includes advertising and promotions, It sometimes includes sales force spending and may also include price promotions (Neil et al., 2006).

Panigyrakis et al. (2009), investigated the contribution of marketing, research and development (R\&D) strategies to the profitability of Greek companies for the period (2000 2004). Results showed that there is no significant relationship between marketing and R\&D intensity and profitability. In other words, R\&D or advertising or branding has no impact on profitability. In addition, Sharma \& Husain (2015), studied the statistical significance of the relationship of Selling \& Marketing Expenses with profitability of all the listed Telecom companies in Kingdom of Saudi Arabia for a period of 4 years (2011 - 2014), with a total of 16 firms. The researchers concluded that there is no significant impact of Selling \& Marketing Expenses on Gross Operating Profitability.

However, Chiliya et al. (2009), studied the impact of marketing strategies on profitability of small grocery shops in Mdantsane, South Africa, where 36 grocery shops were examined within the context of the research framework, marketing strategies such as the promotion of products price and customer service where it played a significant role in the profitability of the studied sample. Also, Chukwuma (2020) investigated the effect of market research on the profitability of real estate investment. The study used random sampling technique to choose 270 firms and the research instrument was closed and open-ended structured questionnaire and face-to interviews for the primary data. Data collected was analysed using simple descriptive and statistical tools. The results showed that there is positive relationship between the quality of market research and real estate investment performance showing that the correlation coefficient of 0.240 significant at $10 \%$ level.

Based on the above, the following hypotheses are developed:

H3a: Marketing Spending strengthening the relationship between Growth in fixed assets and return on assets (ROA). H3b: Marketing Spending strengthening the relationship between Growth in fixed assets and return on assets (ROE).

\section{E. Firm size:}

Caves and Porter (1977) as well as Porter (1979), point out that the relationship between firm size and profitability may vary across industries. Where, Gleason et al. (2000), found that firm size has a positive and significant effect on firm performance measured by return on asset (ROA). On the other hand, other researchers such as Durand and Coeurderoy (2001), and Tzelepis and Skuras (2004), have found an insignificant effect of firm size on the firm's performance.

Lee (2009), answered the question does size matter in firm performance? in his paper, where he re-examined the determinants of firm performance and, in particular, the role that firm size plays in profitability.

He investigated this issue using a sample of more than 7,000 US publicly-held firms during the period (1987-2006), using a fixed-effects dynamic panel data model which provided evidence that profit rates are positively correlated with firm size in a non-linear addition, Velnampy and Nimalathasan (2010), 
studied the relationship between firm size and profitability of all Commercial Bank in Sri Lanka over the period of 10 years from 1997 to 2006. They observed a positive relationship between firm size and profitability.

Whereas Becker et al. (2010), also studied the effects of firm size on profitability in the firms operating in manufacturing sector in USA using the data of years 1987 to 2002. However, the results showed that profitability is negatively correlated with the number of employees.

On the other hand, Niresh and Velnampy (2014), studied the effects of firm size on profitability of quoted manufacturing firms in Sri Lanka. Data of 15 companies which were active in Colombo Stock Exchange (CSE) for the period (2008 to 2012) has been used. Indicators of firm profitability, return on assets and net profit have been used. The correlation and regression methods have been used in the empirical analysis. The results showed that there is no indicative relationship between firm size and profitability of listed manufacturing firms in Sri Lanka.

Based on the above, the following hypotheses are developed:

H4a: Firm size strengthening the relationship between Growth in fixed assets and return on assets (ROA).

H4b: Firm size strengthening the relationship between Growth in fixed assets and return on assets (ROE).

\section{RESEARCH MODEL:}

This study examines the impact of leveraging assets strategy as an independent variable on the financial performance (dependent variable), Focusing on profitability ratios as financial performance proxies, as they are considered the best firm financial performance measures and has a high generality (Tian \& Zeitun, 2005). In addition, the research model includes the moderating variables (firm size and marketing expenses) and the control variables (CEO duality and company age). Figure (2) represents the model of this study.

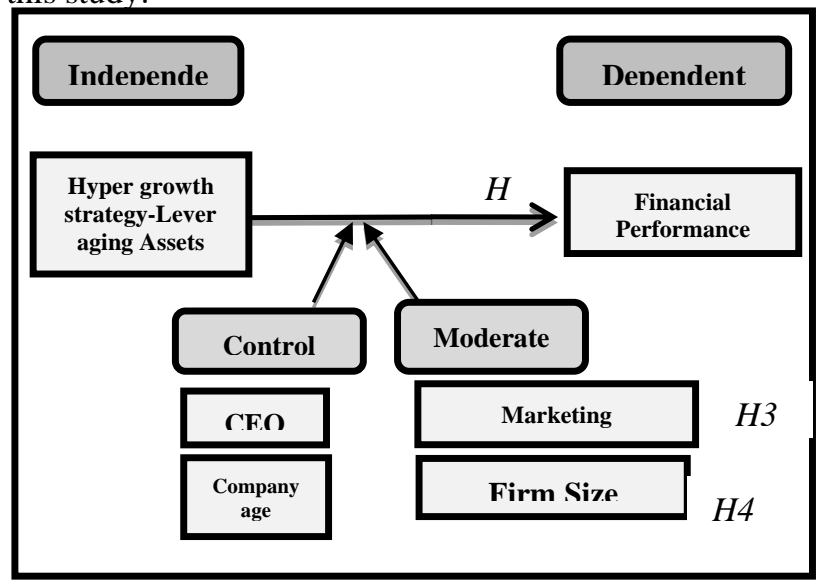

Figure (2): Research Model

\section{DATA AND METHODOLOGY}

Ismail Salim noticed that some companies are growing much faster than others, hence, did a research using a sample of the fortune 500 companies and surveyed the CEOs. He concluded that $80 \%$ agreed that the industries will experience a transformation due to disruptive technology. After that he investigated another sample of the 500 fortune which included only the companies that achieved an accelerating growth in consideration to the company's market value. The new sample, composed of 100 companies, achieved what he called 'exponential growth' (Salim, 2014). After a deep investigation and reviewing for the 100 companies he concluded that these exponential organizations shared the same ten characteristics or growth strategies (MTP).

The population for this study consisted of the 100 exponential organizations out of the fortune 500 , which were investigated by Salim (2014). The sample for the current study was selected depending on the criteria below:

Company should be publicly held during the study period (2016-2019).

All data required for variables calculation are available and accessible during the study period.

The company is not closed or has stopped working during the study period.

Depending on the above criteria, it is noted that only 34 companies met the requirements. The list of the selected companies is shown in Table (1).

Table (I)

\begin{tabular}{|c|c|c|c|c|}
\hline $\mathbf{1}$ & $\mathbf{2}$ & $\mathbf{3}$ & $\mathbf{4}$ & $\mathbf{5}$ \\
\hline UBER & GOOGLE & Pinterest & Etsy & Netflix \\
\hline $\mathbf{6}$ & $\mathbf{7}$ & $\mathbf{8}$ & $\mathbf{9}$ & $\mathbf{1 0}$ \\
\hline Amazon & Facebook & Snapchat & Twitter & Zynga \\
\hline $\mathbf{1 1}$ & $\mathbf{1 2}$ & $\mathbf{1 3}$ & $\mathbf{1 4}$ & $\mathbf{1 5}$ \\
\hline Box & Eventbrite & Dropbox & Splunk & IBM \\
\hline $\mathbf{1 6}$ & $\mathbf{1 7}$ & $\mathbf{1 8}$ & $\mathbf{1 9}$ & $\mathbf{2 0}$ \\
\hline Tesla & Cisco & Workday & ServiceNow & Salesforce \\
\hline $\mathbf{2 1}$ & $\mathbf{2 2}$ & $\mathbf{2 3}$ & $\mathbf{2 4}$ & $\mathbf{2 5}$ \\
\hline Cloudera & Xiaomi & Yelp & Haier & Apple \\
\hline $\mathbf{2 6}$ & $\mathbf{2 7}$ & $\mathbf{2 8}$ & $\mathbf{2 9}$ & $\mathbf{3 0}$ \\
\hline Slack & Alibaba & Groupon & Square & GoPro \\
\hline $\mathbf{3 1}$ & $\mathbf{3 2}$ & $\mathbf{3 3}$ & $\mathbf{3 4}$ & \\
\hline Spotify & Freelancer & $\begin{array}{c}\text { General } \\
\text { Electric }\end{array}$ & Zillow & \\
\hline
\end{tabular}

To achieve the purpose of the study, the secondary data sources were used. Data was collected from annual financial reports published by the official website of "Yahoo Finance" 2 for the period (2016-2019). The study depended on calculated financial ratios published by the same source for the same period. All data was reviewed and filtered by the official website of Wall Street Journal (WSJ)1.

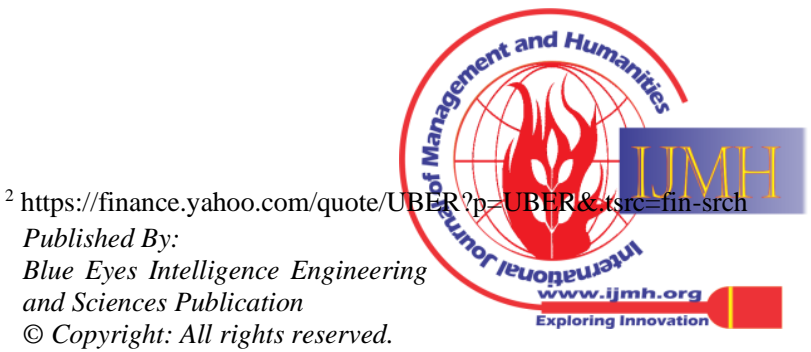




\section{VARIABLES AND MEASURES}

\section{A. Independent Variable}

The leveraging assets growth strategy is operationalized as the growth in assets it is calculated for specific year by the following equation (Gibson, 2008):

"Growth in assets = beginning fixed assets - ending fixed assets + depreciation from the period"

\section{B. Dependent Variable}

The researcher used different measures for corporate performance; The Return on Assets (ROA) and Return on equity (ROE) are representing accounting performance measures used as proxy for the Firm performance

Return on assets (ROA) and return on equity (ROE) are the most commonly used financial performance measures. These accounting measures represent the financial ratios from balance sheets and income statements. The mentioned ratios have been used by many researchers, such as; Demsetz and Lehn (1985), Gorton and Rosen (1995), Mehran (1995), Ang, Cole and Line (2000), and Gibson (2008). The financial

performance measure (ROA) is widely regarded as the most useful measure to test a firm's financial performance (Reese and Cool, 1978; Long and Ravenscraft, 1984).

Return on Equity (ROE): is used to measure how good the company in generating returns on the investment received from its shareholders and calculated by the following formula (Gibson, 2008):

"ROE = net income/ shareholder's equity"

Return on Assets (ROA): Return on total assets measures the firm's ability to utilize its total assets to create profits by comparing profits with the assets that generate the profits. The return on total assets is computed as follows (Gibson, 2008):

\section{"ROA = net income / assets"}

\section{Moderator Variables}

Marketing Spending is reported in the income statement by the firm at the end of each year during the study period.

Firm Size is operationalized as the number of full-time employees. A full-time employee is, for a calendar month, an employee employed on average at least 30 hours of service per week, or 130 hours of service per month.

\section{Control Variables}

CEO Duality is measured by whether a single individual is serving both CEO and board chair or is not. In many cases, the duality has been blamed for the poor performance, and failure of firms to adapt to a changing environment (Krause, Semadeni, \& Cannella, 2014).

The relationship between firm age and firm performance is well documented; Peng, Zhang and Li (2007), concluded that CEO duality asserts a significantly positive influence on ROE and sales growth.

Lee and Lam (2008), examined the relationship between CEO duality and firm performance of a sample of 128 publicly-listed companies in Hong Kong in 2003. They conclude that the relationship is contingent on the presence of the family control factor. CEO duality is good for non-family firms, while non-duality is good for family-controlled firms. Mesut et al. (2013), examined the impact of CEO duality on the firm performance for a sample of 204 listed firms in
Istanbul Stock Exchange (ISE) between the years (2009-2010) in Turkey. The results showed that CEO duality had a negative impact on the firm performance, consistent with the agency theory.

Company age is calculated from the year of foundation to the years of the study period (2016-2019). The relationship between firm age and firm performance is well documented but presents contradicting results (Agarwal \& Gort, 2002). A similar effect was reported by Pastor and Veronesi (2003), who studied the company age and its impact of financial performance for the period of 1962 through 2000.

\section{ANALYSIS PLAN}

The aim of the study is to investigate the impact of the hyper growth strategy- leveraging assets on firm performance; Data was collected for the period 2016 - 2019, and the statistical software Stata (V.15) was used. A Preliminary analysis was conducted to check the assumptions related to the regression models which include unit root, autocorrelation, residuals normality and heteroskedasticity issues. In addition, transforming variables into log provided the best solution for the violated assumptions.

\section{DESCRIPTIVE STATISTICS}

This section displays descriptive statistics for the tested variables using raw data. Descriptive statistics includes measures of central tendency such as the mean, and the standard deviation (SD). Table (II) shows descriptive statistics values for the tested variables.

The descriptive statistics displays mean values for the study variables which recorded (59242.99) for NEmp, (8970000000.00) for MExp,(4770000000.00) for FAssets, (-0.0611594) for ROA,(-0.1402894) for ROE, SD values recorded (128770.6) for NEmp, (16900000000.00) for MExp, (20700000000.00) for FAssets, (0.241394) for ROA, (0.6808971) for ROE. We can clearly notice from the above statistics that this firm's size is very large and spending a lot of dollars on marketing activities on the other hand, we can conclude that it has huge operations and generating a lot of jobs.

\section{Table (II): Descriptive statistics for the study variables}

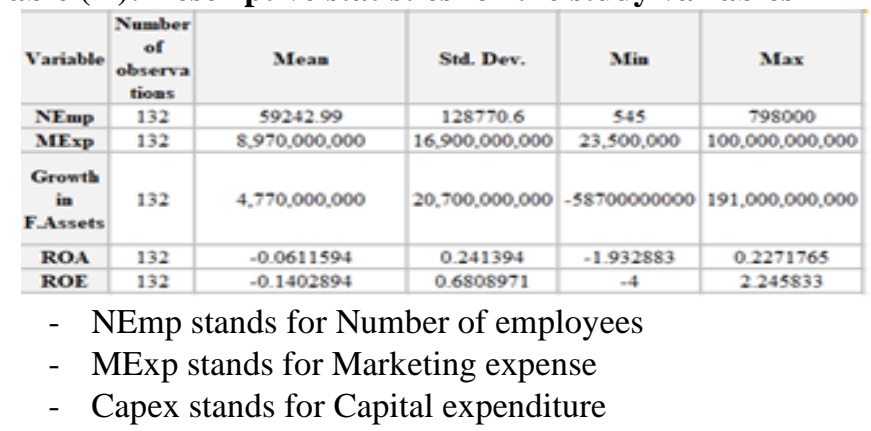

\section{CORRELATIONS}

Pearson correlations analysis was applied to identify the correlation between the variables.

Correlations were recorded after transforming variables into log.

Published By:

Blue Eyes Intelligence Engineering and Sciences Publication

(C) Copyright: All rights reserved. 
In viewing correlations between variables, Growth in FAssets was significantly and positively correlated with $\operatorname{NEmp}\left(\mathrm{r}=.667^{* *}\right)$ and $\operatorname{MExp}\left(\mathrm{r}=.776^{* *}\right)$. ROA recorded significant and positive correlation with NEmp $\left(\mathrm{r}=.484^{* *}\right)$, $\operatorname{MExp}\left(\mathrm{r}=.385^{* *}\right)$, and Growth in FAssets $\left(\mathrm{r}=.450^{* *}\right)$. ROE also recorded significant positive correlations with NEmp ( $r$ $\left.=.322^{* *}\right), \operatorname{MExp}(\mathrm{r}=.228 *)$, and Growth in FAssets $(\mathrm{r}=$ $\left..362^{* *}\right)$. On the other hand, Tobin's Q recorded significant negative correlations with NEmp $\left(\mathrm{r}=-.390^{* *}\right)$ and MExp (r= $\left.-.211^{*}\right)$. Finally, market capitalization was significantly and positively correlated with NEmp $\left(\mathrm{r}=.820^{* *}\right)$, MExp $(\mathrm{r}=$ $\left..646^{* *}\right)$ and Growth in FAssets $\left(\mathrm{r}=.761^{* *}\right)$.

\section{HYPOTHESIS TESTING}

In testing the proposed hypotheses, Ordinary Least Square (OLS) estimation was used to apply regression equations along with transforming all variables into natural log. Six models were established for each dependent variable, the first one entered control variables, and the second model entered the control variables and the predictor variable through a full specification model. The Third model entered control variable, Growth in fixed assets, and the number of employees with the interaction effect Growth in fixed $x$ number of employees (Firm Size). The fourth model examined the interaction effect of Growth in fixed $x$ marketing expenses. The effect of the independent variable on the dependent variable is strengthened by the suggested moderators namely number of employees (Firm Size), and marketing expenses. The current study is concerned with examining the effect of Growth in fixed on ROA, ROE, while using the control variables; the company age and CEO duality. After examining the direct effect, the study included moderation roles for Firm and marketing expenses. The next sections provide the gathered results for testing each hypothesis. To accept the hypothesis it should result with positive and less than 5\% prob rather than it will be rejected.

Growth in fixed assets and ROA (Table III)

Model $1 \rightarrow$ ROA_LOG $=\mathrm{C}(1) * A G E+C(2) * D U A L I T Y+$ $\mathrm{C}(3)$

Model $2 \rightarrow$ ROA_LOG $=\mathrm{C}(1) * A G E+C(2) *$ DUALITY + C(3)*CAPEX_LOG + C(4)

Model $3 \rightarrow$ ROA_LOG $=$ C $(1) * A G E+C(2) *$ DUALITY + C(3)*CAPEX_LOG + C(4)*N_EMP_LOG +

$\mathrm{C}(5) * \mathrm{CAPEX}$ _X_NEMP + C(6)

Model $4 \rightarrow$ ROA_LOG $=\mathrm{C}(1) * A G E+C(2) * D U A L I T Y+$ $\mathrm{C}(3) * \mathrm{CAPEX} \_\mathrm{LOG}+\mathrm{C}(4) * \mathrm{MEXP} \_\mathrm{LOG}+\mathrm{C}(5) * \mathrm{CAPEX}$ _X_MEXP + C(6)

The first model examined the effect of control variables on ROA. The model was not significant as Prob $>F$ recorded (0.9789) exceeding (0.05) level. The amount of variance explained by control variables was marginal and very low $(\mathrm{R} 2=0.03 \%)$. The full specification 2nd model entered control variables along with the predictor namely Growth in assets and the model was significant as Prob $>F$ recorded (0.000). The explained variance recorded $(\mathrm{R} 2=21.19 \%)$ donating low variance. Coefficient of Growth in assets recorded (.0335837) with a Prob (0.000). Providing support for the proposed hypothesis $\mathrm{H} 1$; since the Prob is less that $5 \%$ and the coefficient is positive.

The Third model entered the interaction effect between Growth in FAsssets $\times$ Firm size, which recorded a significant
Prob of (0.000), and a variance of ( $\mathrm{R} 2=30.03 \%)$. The coefficient for FAsssets $\times$ number of employees was significant and recorded a negative effect (-.0091156), concluding that the Firm size was dampening the positive effect between Growth in FAsssets and ROA. Depending on the above findings, this renders no support to hypothesis H4a. The fourth model tested the interaction effect of FAsseets $\times$ Marketing expenses and recorded a significant Prob of (0.000), and achieved a variance increase of ( $R 2=24.45 \%)$ Finally, the coefficient of the interaction effect was positive and insignificant (.0049597), concluding that marketing expenses strengthened the positive effect between FAsseets and ROA, Depending on the above findings, this renders no support to hypothesis HЗa.

Table (III): Effect of Growth in FAssets $\rightarrow$ ROA

\begin{tabular}{|c|c|c|c|c|}
\hline $\begin{array}{l}\text { Entered } \\
\text { variable }\end{array}$ & Model (1) & Model (2) & Model (3) & Model (4) \\
\hline $\begin{array}{l}\text { Age } \\
\text { centiont }\end{array}$ & -0.00034 & 0.001661 & 0.000516 & 0.001982 \\
\hline Prat & $\underline{0.848}$ & $\underline{0.338}$ & 0.759 & $\underline{0.25}$ \\
\hline \multirow{2}{*}{ Duality } & -0.00266 & 0.016625 & 0.005619 & 0.028894 \\
\hline & $\underline{0.942}$ & $\underline{0.64}$ & $\underline{0.871}$ & $\underline{0.424}$ \\
\hline \multirow{2}{*}{ CAPEX } & \multirow{2}{*}{-} & 0.033584 & 0.104459 & -0.07787 \\
\hline & & $\underline{\mathbf{0}}$ & $\underline{0.014}$ & $\underline{0.204}$ \\
\hline \multirow{2}{*}{$\begin{array}{c}\text { Growth } \\
\text { in } \\
\text { FAssets } x\end{array}$} & \multirow{2}{*}{ - } & \multirow{2}{*}{ - } & -0.00912 & \multirow{2}{*}{-} \\
\hline & & & $\underline{0.037}$ & \\
\hline \multirow{2}{*}{$\begin{array}{l}\text { Growth } \\
\text { in } \\
\text { FAssets }\end{array}$} & \multirow{2}{*}{ - } & \multirow{2}{*}{ - } & & 0.00496 \\
\hline & & & & $\underline{0.091}$ \\
\hline \multirow{2}{*}{ Constant } & -0.04629 & -0.78461 & -2.5463 & 1.183187 \\
\hline & $\underline{0.38}$ & $\underline{0}$ & $\underline{0.004}$ & $\underline{0.353}$ \\
\hline $\mathbf{R}^{2}$ & 0.0003 & 0.2119 & 0.3003 & 0.2445 \\
\hline Prob $>$ F & $\underline{0.9789}$ & $\underline{\mathbf{0}}$ & $\underline{0}$ & $\underline{\mathbf{0}}$ \\
\hline
\end{tabular}

Table (IV): Effect of Growth in FAssets $\rightarrow$ ROE

\begin{tabular}{|c|c|c|c|c|}
\hline $\begin{array}{l}\text { Entered } \\
\text { variable }\end{array}$ & Model (1) & Model (2) & Model (3) & Model (4) \\
\hline Age cueffacts & -0.00408 & 0.00073 & -0.00167 & 0.001206 \\
\hline Prat & $\underline{0.365}$ & 0.871 & $\underline{0.715}$ & $\underline{0.791}$ \\
\hline \multirow{2}{*}{ Duality } & 0.071882 & 0.12415 & 0.110604 & 0.141183 \\
\hline & $\underline{0.454}$ & 0.195 & 0.248 & 0.154 \\
\hline \multirow{2}{*}{ CAPEX } & \multirow{2}{*}{  } & 0.06695 & 0.175591 & -0.14785 \\
\hline & & $\underline{\mathbf{o}}$ & $\underline{0.129}$ & $\underline{0.363}$ \\
\hline \multirow{2}{*}{$\begin{array}{l}\text { Growth in } \\
\text { FAssets } \% \\
\text { Number of }\end{array}$} & \multirow{2}{*}{ - } & \multirow{2}{*}{ - } & -0.01469 & \multirow{2}{*}{ - } \\
\hline & & & $\underline{0.215}$ & \\
\hline \multirow{2}{*}{$\begin{array}{l}\text { Growth in } \\
\text { FAssets } M \\
\text { Marketing }\end{array}$} & \multirow{2}{*}{-} & \multirow{2}{*}{ - } & \multirow{2}{*}{ - } & 0.009931 \\
\hline & & & & 0.201 \\
\hline \multirow{2}{*}{ Constant } & -0.01909 & -1.54134 & -4.39896 & 2.541054 \\
\hline & $\underline{0.887}$ & $\underline{\mathbf{o}}$ & $\underline{0.065}$ & $\underline{0.451}$ \\
\hline $\mathbf{R}^{2}$ & 0.0115 & 0.1468 & 0.1971 & 0.1636 \\
\hline Prob $>$ F & 0.5067 & 0.0017 & 0.0009 & 0.0047 \\
\hline
\end{tabular}

\section{Growth in Fixed Assets and ROE - (Table IV)}

The following equations were used to estimate the suggested models:

Model 1: ROE_LOG=C(1)*AGE+C(2)*DUALITY + C(3)

Model 2: ROE_LOG $=\mathrm{C}(1) * \mathrm{AGE}+\mathrm{C}(2) * \mathrm{DUALITY}+$ $\mathrm{C}(3) * \mathrm{CAPEX} \_\mathrm{LOG}+\mathrm{C}(4)$

Model 3: ROE_LOG $=\mathrm{C}(1) * \mathrm{AGE}+\mathrm{C}(2) *$ DUALITY + $\mathrm{C}(3) * \mathrm{CAPEX} \_$LOG +

C $(4) * N \_E M P \_L O G+C(5) * C A P E X \_X \_N E M P+C(6)$

Model 4: ROE_LOG $=\mathrm{C}(1) * \mathrm{AGE}+\mathrm{C}(2) * \mathrm{DUALITY}+$ $\mathrm{C}(3) * \mathrm{CAPEX} \_L O G+\mathrm{C}(4) * \mathrm{MEXP} \_L O G+\mathrm{C}(5) * \mathrm{CAPEX}$ _X_MEXP + C(6)

Depending on the above, the results are summarized: 


\section{Exponential Organizations Hypergrowth Strategies and Firm Performance: The Moderating Role of Firm Size and Marketing Spending}

Growth in FAssets has a significant positive impact on financial performance with prob of $(0.00)$ and coefficient of .0335 for ROA, where ROE reported $(0.00)$ as prob and coefficient of .0669. Depending on these results the growth in Fixed Assets is positively affecting companies earning and leveraging assets hypergrowth strategy (renting assets instead owning them) is negatively affecting the firms earning. The moderating role of marketing expenses and firm size showed an insignificant impact in the relationship between FAssets and financial performance measured by ROA and ROE.

\section{DISCUSSION OF FINDINGS}

This study draws Managers and researcher attentions in considering factors that affect the strategic decisions and enhancing firm's hypergrowth Ability; specifically, for those who are managing the startups, high growth firms and entrepreneurs. It highlights the significance of investing in assets decision and its impact on the firm performance. It also contributes in reducing the ambiguity through explaining the new business model (EXOs) and identifying factors that contribute to its hypergrowth. The study took into consideration the fact that growth in assets is not the only variable that has an impact on financial performance, consequently, other variables affecting financial performance were analysed such as: firm size which is measured by number of employees, and marketing expenses as well.

The results showed that the Growth In assets has a significant positive correlation to financial performance measured by ROA and ROE. Yet, the coefficient is relatively low. The ROA reported (0.00) prob and (.0335837) coefficient. On the other hand, the ROE reported (0.00) prob and (.0669496) coefficient. Depending on these results, it is noticed that the ROE affected by the change in Growth in Assets more than ROA does. Other studies reported the same positive correlation but the coefficient was more than two. As noted by Tian and Taian et al. (2005), who reported (2.96) for ROA and (1.9) for ROE. The difference in the coefficient value resulting from different study samples is due to their industries. The control variables do not have an impact on the relationship between FAssets and financial performance as they reported prob above $5 \%$ which is insignificant.

R-Square represents the proportion of the variance for a dependent variable which is explained by independent variables in a regression model. The reported R- Square for ROA and ROE is $21.19 \%$ and $14.86 \%$ respectively. This means that there could be other factors affecting the relationship, which researchers must identify. Decision makers should pay more attention to such factors to boost the firm performance.

The moderator variables in the relationship between Growth in FAssets and ROE reported insignificant results. The moderators in the relationship between Growth in FAssets and ROA; reported (-.0091156) prob for Firm size it does not support the hypothesis but it points out a significant negative relationship. It reduces the impact of Growth in FAssets on ROA, but also increases R-Square from (0.2683) to (0.3003). These results are consistent with the hypergrowth strategies of exponential organizations developed by Salim (2014), who found that leveraging employees and decreasing the number of full-time employees has a positive impact on firm's performance, i.e., paying employees only when the task is done. For example, the company Uber, does not pay their drivers until the customer reaches his/her destination. On the other hand, marketing expenses, reported (.215) as prob recorded a positive yet insignificant relationship. This contradicts the main reason for marketing expenses, which is to generate more revenues and profits. The insignificance of marketing expenses may be an indicator of issues in marketing strategy. The above results of FAssets impact on financial performance were confirmed with the results of Zhang (2017), Qaddoumi (2015), Azadi (2013), and Hsiang et al. (2006), and contrasted with Xing (2008), who reported a negative impact. The inconsistency of Xing's results with the rest could be due to the sample he used which was focused in USA companies, and also ignored whether or not the firms within the sample were publicly held, and lastly had no consideration for the time period. The current study results also contrast studies by Cooper at al. (2008), who used the same method and the same time period of Xing's study. Other contrasting studies also include, Kotšina and Hazak (2012), as well as, Svetlana and Aaro (2012), noting that these studies tested samples from the European Union for the same time period, and both concluded that there is no impact of Capex on financial performance.

Finally, we can conclude that Exponential organizations (EXOs) are making high effective decisions regarding investments in assets to achieve high growth in firm performance. Moreover, EXOs are efficient in utilizing their assets to achieve hypergrowth. This is one of the strategic reasons standing behind the hypergrowth and exponential organization. But this is not confirmed with what Salim, (2014) reported for the results of leveraging assets; this study conclude there is a positive relationship between fixed assets growth and firm performance and leveraging assets or renting them will negatively affecting firm performance.

\section{GENERALIZABILITY}

The generalizability of this study's findings would be limited to fortune 500 specially those achieving accelerated growth rates.

\section{FUTURE STUDIES:}

Suggestions for future researches are as follows:

A study may be conducted with a longer time period and with more observations.Researchers may use firm size, measured by the number of employees as an independent variable, since it is one of EXOs characteristics. The number of employees can also be measured, as a percent of fixed assets (dividing number of employees on fixed assets) in order to take into consideration differences in companies' sizes.

Researchers could use other moderator variables, such as: research and development, CEO compensation and employee's satisfaction.

Researchers could use other control variables, such as; the industry and make groups of firm ages where each group represents an interval. 
Researchers could study the impact of other characteristics of EXOs on firm market value as well as the impact of the firm value on the profit.

Researchers should consider the risks from leveraging assets and employees; for example, employees' loyalty and the termination of assets provider.

\section{REFERENCES}

1. Adam, S. (2011). the Goal of Maximizing Shareholder Wealth. Christian Business Academy Review, 6(1), 50-62.

2. Agarwal, R., \& Gort, M. (2002). Products and firm life cycles and firm survival. American Economic Review, 92(2), 184-190.

3. Ang, J., Cole, R., \& Line, W. (2000). Agency Costs and Ownership Structure. Journal of Finance, 55(1), 81-106.

4. Azadi , M. (2013). The relationship between changes in asset structure and operating earnings in the Tehran Stock Exchange (TSE). Trends in Advanced Science and Engineering, 11(2), 170-179.

5. Becker-Blease, J., Kaen, F., Etebari, A., \& Baumann, H. (2010). Employees, firm size and profitability in U.S. manufacturing industries. Investment Management and Financial Innovations, 7(2), 7-23.

6. Bonchek, M. (2016). How to Create an Exponential Mindset. Harvard business review .

7. Bruce, R., \& scott, M. (1987). Five stages of growth in small business. Long range planning, 20(1), 45-52.

8. Caves, R., \& Porter, M. (1977). From entry barriers to mobility barriers: Conjectural decisions and contrived deterrence to new competition. Quarterly Journal of Economics, 91(2), 421-441.

9. Chiliya, N., Herbst, G., \& Roberts, M. (2009). The impact of marketing strategies on profitability of small grocery shops in South African townships. African Journal of Business Management, 3(3), 70-79.

10. Chukwuma, N. J. (2020). The effect of quality market research on the performance / profitability of real estate investment in emerging economies. Journal of Business \& Management, 8(3), 139-155.

11. Demsetz, H., \& Lehn, K. (1985). The Structure of Corporate Ownership: Causes and Consequences. Journal of Political Economy, 93(6), 1155-1177.

12. Durand , R., \& Coeurderoy, R. (2001). Age, Order of Entry, Strategic Orientation, and Organizational. Journal of Business Venturing, 16(5), 471-494.

13. Eisenmann, T. (2006). Internet companies' Growth strategies: Determinants of investment intinsity and long-term performance. Harvard Graduate School of Business Administration, 27(1), 1183-1204.

14. Eriotis, N., Frangouli, A., \& Neokosmides, Z. (2000). Profit Margin and Capital Structure: An Empirical Relationship. The Journal of Applied Business Research, 18(2), 1-3.

15. Fudenberg, D., \& Tirole, J. (1987). Understanding rent dissipation:on the use of game theory in industrial organization. American Economic Review, 77(2), 176-183.

16. Gleason, K., \& Mathur, I. (2000). The Interrelationship between European Retailers. Journal of Business Research, 50(2), 185-191.

17. Gorton, G., \& Rosen, R. (1995). Corporate Control, Portfolio Choice, and the Decline of Banking. Journal of Finance, 50(5), 377-420.

18. Greiner, L. (1998). Evolution and revolution as organizations grow (updated). Harvard Business Review, 76(3), 55-68.

19. H.gibson, c. (2008). Financial Reporting and Analysis (Vol. 11). USA: LEAP Publishing Services.

20. Hagel, J. (2002). Leveraged Growth: Expanding Sales Without Sacrificing Profits. USA: Harvard business reriew.

21. Hanks, S., \& Chandler, G. (1994). Patterns of functional specialization in emerging high tech firms. Journal of Small Business Management, 32(2), 23-36.

22. Hoffer, C., \& Sandberg, R. (1987). Improving new venture performance: some guidelines for success. American Journal of Small Business, 12(1), $11-25$ Culture, Capital Structure, and and Performance: Evidence from

23. Hsiang, L., Ching, H., \& Yen. (2006). Capital expenditures and corporate earnings: Evidence from the Taiwan Stock Exchang. Managerial finance,, 32 (11), 853 - 861.

24. Izosimov, A. V. (2008). Managing Hypergrowth. Harvard Business review .

25. Kabaly, P., \& Balanagarajan, K. (2018). Exponential Organization: Paytm - A Review. Journal of enterprise information system, 10(3), 35-40.

26. Kazanjian, R., \& Drazin, R. (1990). A stage-contingent model of design and growth for technology based new ventures. Journal of Business Venturing, 5(3), 137-150.

27. Kotšina, S., \& Hazak, A. (2012). Does investment intensity impact company profitability? A cross-country empirical study. the 2nd International Conference on Economics, Trade and Development. 36, pp. 157-161. Bangkok: IACSIT Press.

28. Krause, R., Semadeni, M., \& Cannella, A. J. (2014). CEO Duality: A Review and Research Agenda. Journal of Management, 40(1), 252-282.

29. Lee, J. (2009). Does Size Matter in Firm Performance? Evidence from US Public Firms. International Journal of the Economics of Business, 16(2), 189-203.

30. Lee, S. K., \& Lam, T. Y. (2008). CEO duality and firm performance: evidence from Hong Kong. Corporate Governance journal, 8(3), 299-316.

31. Lieberman, M. (2002). Did first-mover advantage survive the dot-com crash? Graduate School of Management, 1, 441-452.

32. Long, W., \& Ravenscraft, D. (1984). The Misuse of Accounting Rates of Return: Comment. American Economic Review, 74(3), 494-500.

33. Markman, G., \& Gartner, W. (2002). The Effects of Hyper Growth on Firm Profitability. The Journal of Private Equity, 4, 58-65.

34. MCGareth , J., \& Kroeger , F. (2001). The value of growers: Acheiving competitive advantage through long term growth and profit (Vol. 10). Boston: McGraw-Hill.

35. Mehran , H. (1995). Executive Compensation Structure, Ownership, and Firm Performance. Journal of Financial Economics, 38(2), 163-184.

36. Mesut, D., Bilge , E., AĞCA, V., \& ÖGEL, S. (2013). The Impact of CEO Duality on Firm Performance: Evidence From Turkey. International Journal of Business and Social Science, 4(2), 149-155.

37. Panigyrakis, G., Kapareliotis, I., \& Ventoura , Z. (2009). Marketing and corporate profitability: the case of Greek firms. Managerial Finance, 35(11), 909-917.

38. Pastor , L., \& Veronesi, P. (2003). Stock valuation and learning about profitability. Journal of Finance, 58(5), 1749-1789.

39. Peng, M., Zhang, S., \& Li, X. (2007). CEO Duality and Firm Performance during China's Institutional Transitions. Wiley Online Library, 3(2), 205-224.

40. Porter , M. (1979). The structure within industries and company performance. Review of Economics and Statistics, 61(2), 214-227.

41. Qaddoumi , T. (2015). The impact of Capitl expenditure on financial performance - study on manufacturing sectore for companies listed in Amman sttock Exchange. Jordan jornal for applied science(1), 16-23.

42. Ramli, A., \& Yusoff, R. Z. (2015). Strategic Planning and Firm Performance: A Proposed Framework. International Academic Research Journal of Business and Technology, 1(2), 201-207.

43. Reese, J., \& Cool, W. (1978). Measuring Investment Centre Performance. Harvard Business Review, 2(1), 28-46.

44. Rutherford, M, W., Buller, \& McMullen. (2003). Human resource management problems over the life cycle of small to medium-sized firms. Human Resource Management, 7(2), 64-79.

45. Sahu, A., Robert, K., \& Farragher, E. (2001). THE ASSOCIATION BETWEEN THE USE OF SOPHISTICATED CAPITAL BUDGETING PRACTICES AND CORPORATE PERFORMANCE. The Engineering Economist, 46(4), 300-311.

46. Salim, I. (2014). Exponential Organizations: Why new organizations are ten times better, faster, and cheaper than yours. New york: Diversion Books. 
47. Sánchez-Vidal, J., \& Francisco, J. (2005). Financing Preferences of Spanish Firms: Evidence on the Pecking Order Theory. Review of Quantitative Finance and Accounting, 25(4).

48. Sextone, D., Pricer, R., \& Nenide, B. (2000). Babsons entreprenuership research Confirence. (pp. 172-186). Chicago: wellesley mass.

49. Sharma, K. J., \& Husain, S. (2015). Marketing Expenses \& Profitability: Evidence from Telecom Sector in Kingdom of Saudi Arabia. European Journal of Business and Management, 7(35), 66-70.

50. Spicer, D., \& Sadler-Smith, E. (2006). Organisational learning in smaller manufacturing. International Small Business Journal,, 24(2), 133-158.

51. Svetlana, \& Aaro. (2012). Does Investment Intensity Impact Company Profitability? A Cross- Country Empirical study. 2nd International Conference on Economics, Trade and Development, 36(2), 157-161.

52. Tian , G., \& Zeitun, R. (2005). Capital Structure and Corporate Performance: Evidence from Jordan. Australasian Accounting Business \& Finance Journal, 1(1), 1-36.

53. Tzelepis, D., \& Skuras, D. (2004). The Effects of Regional Capital Subsidies on Firm Performance: An Empirical. Journal of Small Business and Enterprise Development, 11(1), 121-129.

54. Velnampy, T., \& Nimalathasan, B. (2010). Firm Size on Profitability: A Comparative Study of Bank of Ceylon and Commercial Bank of Ceylon Ltd in Sri Lanka. Global Journal of Management and Business Research, 2, 96-100.

55. Zhang, N. (2017). Relationship between intangible assets and financial. African Journal of Business Management, 24(1), 751-757.

\section{AUTHORS PROFILE}

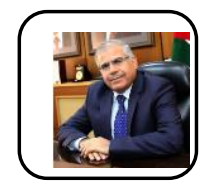

Professor/ Refat Abdelhalim Alfaouri President of Yarmouk University 2015-2017

- Chairman of Yarmouk University Council.

- Chairman of Yarmouk Deans Council.

- Member of the Board of Directors for Irbid Governate Electricity Company.

- Chairman of the Investment Fund at Yarmouk University.

- Member of the Board of Directors at the Oman College for Management and Technology.

- Director General Arab Administrative Development Organization - League of Arab State.

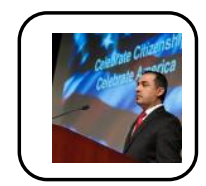

Professor/ Hussam AL-shammari Indiana University of Pennsylvania.

$-\mathrm{PhD}$, University of Texas at Arlington, Strategic Management - Operations Management Minor, 2006

- MBA, Yarmouk University, 1998

- BA, Yarmouk University, Business

Management, 1995.

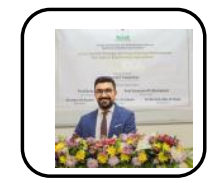

Hamza Tubaishat/ Masters of Business Administration- Yarmouk University,

- Bachelour Accounting/ Yarmouk University.

- Country Financial controller/ Bremen oversea.

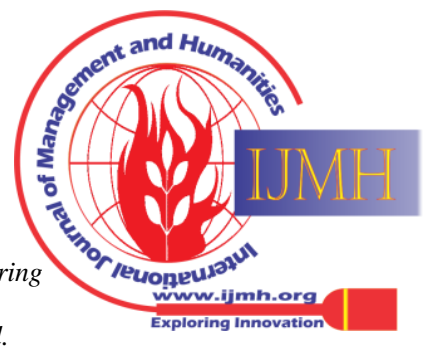

